\title{
Kesahan dan Kebolehpercayaan Modul I-Sc (Islamic Spiritual Counseling) ke atas Pelajar Bermasalah Tingkah Laku
}

\author{
Validity and Reliability of Islamic Spiritual Counselling Module on \\ Troublesome Students
}

\author{
MD NOOR SAPER*, NURUL AIN MOHD DAUD \& NORAZANI AHMAD1
}

\begin{abstract}
The purpose of this study is to develop a counselling module based on Islamic perspective namely 'Islamic Spiritual Counselling Module'"(i-SCM). This module was based on model of Tazkiyat al-Nafs by Imam Ghazali. Validity test was conducted based on assessments from various experts of psychology, counselling and religious fields. Reliability test was conducted on 46 secondary school students in one school. Results obtained showed that the overall reliability coefficient of this module was very high; Cronbach Alpha 0.927. Feedback from the respondents on the module was positive. This study could help expand further religion-related counseling module to assist counsellors in dealing with adolescents' social problems.
\end{abstract}

Keywords: Islamic counselling, module development, psycho-spiritual counselling

Kaunseling dalam istilah Arab merujuk kepada 'al-irsyad' atau 'al-istisyarah' (al-Khuli 1988). Bimbingan pula dikenali sebagai 'al-tawjih'. Ia melibatkan proses yang melibatkan perhubungan bersemuka samada secara individu atau kelompok yang dibantu oleh kaunselor dalam proses memahami dan membantu menyelesaikan permasalahan. Formula kepada kaunseling Islam adalah bersandarkan kepada wahyu Allah daripada al-Quran dan al-Hadith untuk mencapai kesejahteraan di dunia dan akhirat. Rasulullah (s.a.w.) sendiri merupakan contoh Rasul yang mengamalkan konsep kaunseling Islam. Baginda banyak memberi tunjuk ajar dan proses kepada sahabat-sahabat baginda berlandaskan kepada konsep kaunseling Islam.

Aspek spiritual daripada perspektif Islam bukan sekadar satu sistem kepercayaan kepada Tuhan tetapi ia dikenali sebagai 'al-din' iaitu merangkumi satu sistem kehidupan yang menyeluruh yang mempunyai peraturan dan syariat (Ramli 1997; Haron Din 2007). Asas pendekatan dalam agama ialah kerendahan diri yang mana kaunseling tidak menuntut untuk mengarah klien tetapi memerlukan kedua-dua belah pihak mempunyai kepercayaan dalam aspek spiritual manusia dan perhubungan mereka. Konsep spiritualiti bukanlah hanya berkaitan dengan perhubungan interpersonal atau hanya mengiktiraf klien sebagai manusia tetapi menghubungkaitkan antara diri manusia itu dengan Pencipta iaitu Allah. Setiap individu merupakan ciptaan yang sempurna yang mempunyai keupayaan yang unik. Kaunselor mempunyai keupayaan meneroka dalam diri klien (makna, imaginasi, memori, pemikiran dan

\footnotetext{
${ }^{1}$ Md Noor Saper*(Corresponding author), Ph.D., senior lecturer at Dept. of Psycology and Counseling, Faculty of Education and Human Development, Sultan Idris University of Education, 35900 TANJUNG MALIM, Perak, Malaysia, email: md.noor@fppm.upsi.edu.my; Nurul Ain Mohd Daud, Ph.D., senior lecturer at Dept. of Psycology and Counseling, Faculty of Education and Human Development, Sultan Idris University of Education, 35900 TANJUNG MALIM, Perak, Malaysia, email: nurul.ain@fppm.upsi.edu.my; Norazani Ahmad, M.A., lecturer at Dept. of Psycology and Counseling, Faculty of Education and Human Development, Sultan Idris University of Education, 35900 TANJUNG MALIM, Perak, Malaysia, email: norazani@fppm.upsi.edu.my.
} 
perasaan) yang membolehkan perhubungan kaunselor dan klien diikat dengan rahmat dari Allah. Perhubungan tersebut menjurus kepada tujuan sebenar kehidupan iaitu untuk beribadah kepada Allah. Justeru, untuk mencapai tujuan tersebut memerlukan kepada keperluan untuk menghubungkan diri klien dengan Pencipta dan serta memenuhi fungsi klien untuk kehidupan yang lebih bermakna.

Sarjana barat telah mula mengalih pandangan kepada bimbingan dan kaunseling yang mencerap unsur-unsur spiritual dan agama. Terdapat banyak artikel yang ditulis mengaitkan isu agama dan kerohanian dalam kesihatan mental seperti kaunseling dan psikoterapi diterbitkan dalam jurnal-jurnal utama dalam bidang ini (Burke et al. 1999), di samping pembentangan di konvensyen dan seminar kesihatan mental (Sapora 2009). Ramai pengkaji telah membincangkan kerelevanan isu spiritual dalam kaunseling dan psikoterapi (Allen et al. 2004; Graham et al. 2001).

Pengiktirafan terhadap keperluan agama dalam proses membantu tidak boleh dinafikan. Justeru itu tidak hairanlah jika pendekatan agama dan spiritual semakin berkembang di barat. Menurut Sapora (2009), aspek agama dan kerohanian menjadi semakin penting apabila beberapa organisasi profesional seperti American Psychological Association (APA) dan American Counseling Association telah mengiktiraf dan mengakui bahawa agama adalah satu elemen yang perlu dihormati. APA meletakkan religiositi pada division ke-36 sebagai salah satu bahagian daripada beberapa bahagian psikologi yang diiktiraf. Menurut APA, elemen agama merupakan antara faktor yang membantu kefungsian kehidupan manusia (American Psychological Association 2011).

Namun demikian, kajian dan penyelidikan dalam ruang lingkup penggunaan modul bimbingan dan kaunseling elemen spiritual dan keagamaan termasuklah berperspektif Islam tidak banyak dilakukan di dalam negara dan juga di luar negara. Keadaan ini menunjukkan kesedaran tentang pendekatan berperspektif agama masih belum memberangsangkan di samping belum bersedia untuk membuat kajian dengan perkara ini. Paling hampir dengan kajian berkenaan ialah kaunseling pelbagai budaya yang membicarakan persoalan keagamaan dan kerohanian. Ini tidak bermakna tidak ada ahli psikologi dan kaunseling yang membicarakan pendekatan bimbingan dan kaunseling dari perspektif agama (Wan Abd Kader \& Ismail 2006).

Usaha untuk memantapkan satu perspektif baru terhadap pendekatan psikologi dan kaunseling berlandaskan Islam merupakan satu keperluan dan perlu ditingkatkan. Umumnya ia sudah mula menampakkan usaha dalam kalangan ahli psikologi dan kaunseling Islam sama ada dari dunia Islam atau Malaysia mengorak langkah untuk mencapai matlamat ini (Wan Abd Kader \& Ismail 2006). Namun demikian, pendekatan aspek keagamaan masih terdapat kekurangan terutama dari sudut kerangka teoretikal yang mantap serta dapat dijadikan sebagai pedoman kepada kaunselor untuk menjelaskan dan meramal tingkah laku, seterusnya memperbaiki atau merubah tingkah laku yang tidak berkesan (Wan Abd Kader \& Ismail 2006; Sapora 2007).

Pembinaan modul keagamaan merupakan satu keperluan yang boleh membantu kaunselor dalam perkhidmatan mereka. Namun demikian, modul bimbingan yang mendasari elemen keagamaan untuk perkembangan diri pelajar belum dibina dan digunakan secara meluas di sekolah. Pembinaan dan penggunaan modul keagamaan diperlukan kerana ia dapat membantu memperkembangkan potensi diri pelajar meliputi aspek kerohanian, jasmani, emosi, intelek, sosial akhlak dan estetika.

Melihat kepada kepentingan modul keagamaan dalam membantu tugas-tugas kaunselor, maka kajian kepada pembinaan modul keagamaan yang berkualiti adalah wajar. Modul keagamaan ini boleh dijadikan sebagai salah satu bentuk intervensi yang boleh digunakan untuk menangani pelbagai isu salah laku di samping membantu perkembangan diri pelajar. Soalan kajian ini adalah: Apakah nilai pekali kesahan modul secara keseluruhan? Apakah nilai pekali kesahan sub modul? Apakah nilai pekali kebolehpercayaan modul secara keseluruhan? dan, pakah nilai pekali kebolehpercayaan sub modul? 


\section{Objektif Kajian}

Selari dengan tujuan kajian, objektif kajian yang digariskan adalah seperti berikut:

1. Menilai kesahan kandungan keseluruhan modul oleh pakar.

2. Menilai kesahan kandungan sub modul oleh pakar.

3. Mengkaji nilai kebolehpercayaan modul secara keseluruhan.

4. Mengkaji nilai kebolehpercayaan sub modul.

\section{Kerangka Teori Tazkiyat al-Nafs al-Ghazali}

Imam al-Ghazali melihat pembinaan personaliti seseorang merangkumi keseluruhan individu secara sepadu. Ia meliputi dua sepek utama iaitu aspek jasmani dan rohani (al-Ghazali 2007). Kedua-dua aspek ini saling mempengaruhi antara satu sama lain. Namun demikian aspek kerohanian lebih mempunyai pengaruh terhadap perkembangan dan perlakuan personaliti seseorang.

Modul kaunseling psiko-spiritual perspektif Islam berasaskan model yang disesuaikan dengan model Tazkiyat al-Nafs al-Ghazali oleh Salasiah (2008). Ia merupakan satu pendekatan kepada proses pembentukan diri melalui kesedaran dan celik akal untuk membuang sifat dan tingkah laku negatif yang bercanggah dengan norma masyarakat serta kehendak agama serta menimbulkan kecelaruan dan ketidaktenteraman kepada jiwa. Ia dilakukan dengan mengenal diri, kekuatan dan kelemahannya, tingkah laku negatif yang merosakkannya, serta tindakan untuk menghindari sifat berkenaan. Proses ini diikuti dengan usaha peningkatan kualiti jiwa dengan mengembangkan sifat-sifat positif secara terfokus, dengan penuh kesungguhan atau mujahadah sehingga melahirkan tingkah laku baru yang positif.

Model penyucian diri al-Ghazali (tazkiyat al-nafs) meletakan lima konstruk utama iaitu mengenali diri (ma'rifah al-nafs), pembersihan hati (takhalli), pengisian hati (tahalli), penilaian kendiri (muhasabah) dan matlamat kebahagiaan (al-sa'adah). Ia merupakan satu proses rawatan yang melalui beberapa tahap bagi mewujudkan kesejahteraan kepada klien. Model Modul Kaunseling Psiko-spiritual i-SC dapat dilihat dalam berikut:

Rajah 1: Model Tazkiyat al-Nafs al-Ghazali (disesuaikan dengan model al-Ghazali: Salasiah 2008)

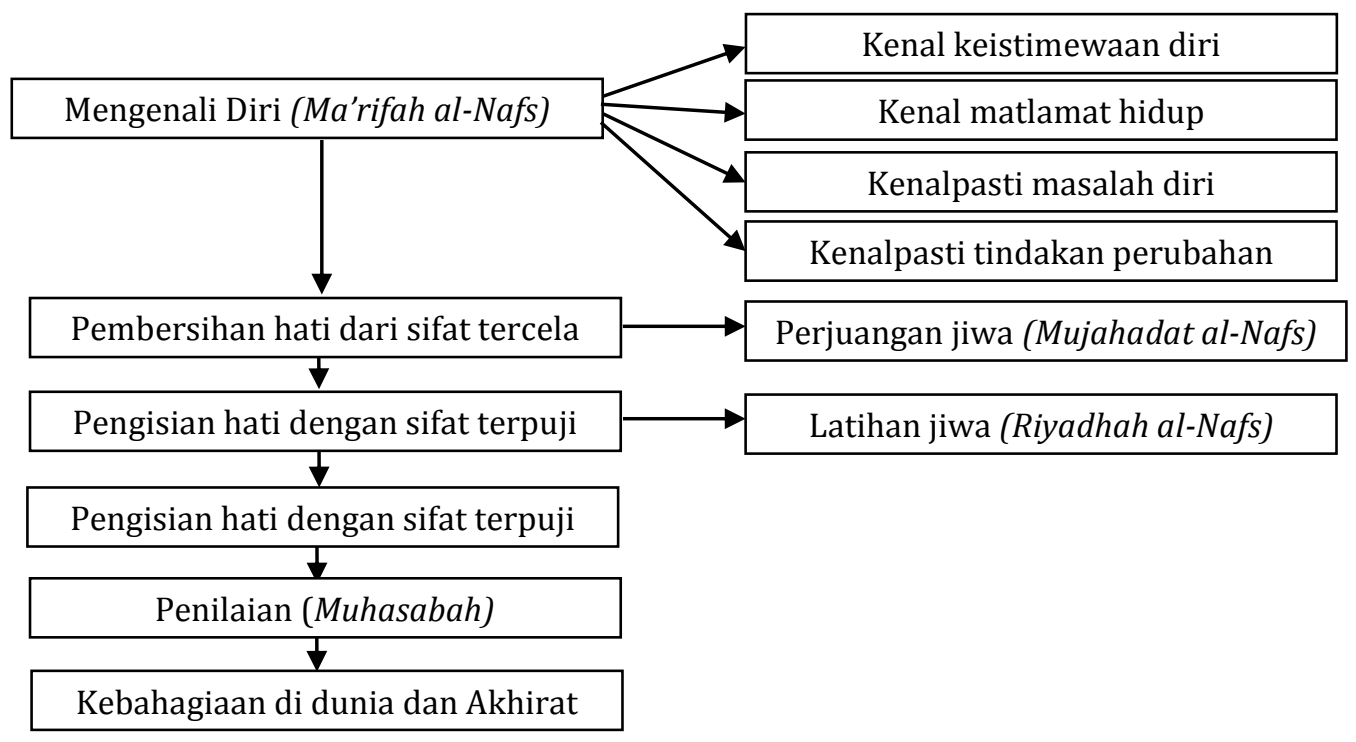




\section{Model Pembinaan Modul i-SC}

Prosedur pembinaan modul dalam kajian ini adalah merujuk kepada model pembinaan oleh modul oleh Sidek dan Jamaludin (2005). Mereka telah memperkenalkan satu model pembinaan modul integrasi yang lebih komprehensif. Model ini melibatkan dua peringkat iaitu peringkat menyediakan draf modul dan peringkat mencuba dan menilai modul. Peringkat penyediaan draf mempunyai sembilan langkah bermula dengan membina matlamat sehinggalah penyatuan draf modul. Manakala peringkat kedua iaitu mencuba dan menilai. Model pendekatan pembinaan modul ini dapat dilihat dalam rajah berikut:

Rajah 2: Model Reka Bentuk Pembinaan Modul Sidek dan Jamaludin (Sumber: Sidek \& Jamaludin 2005)

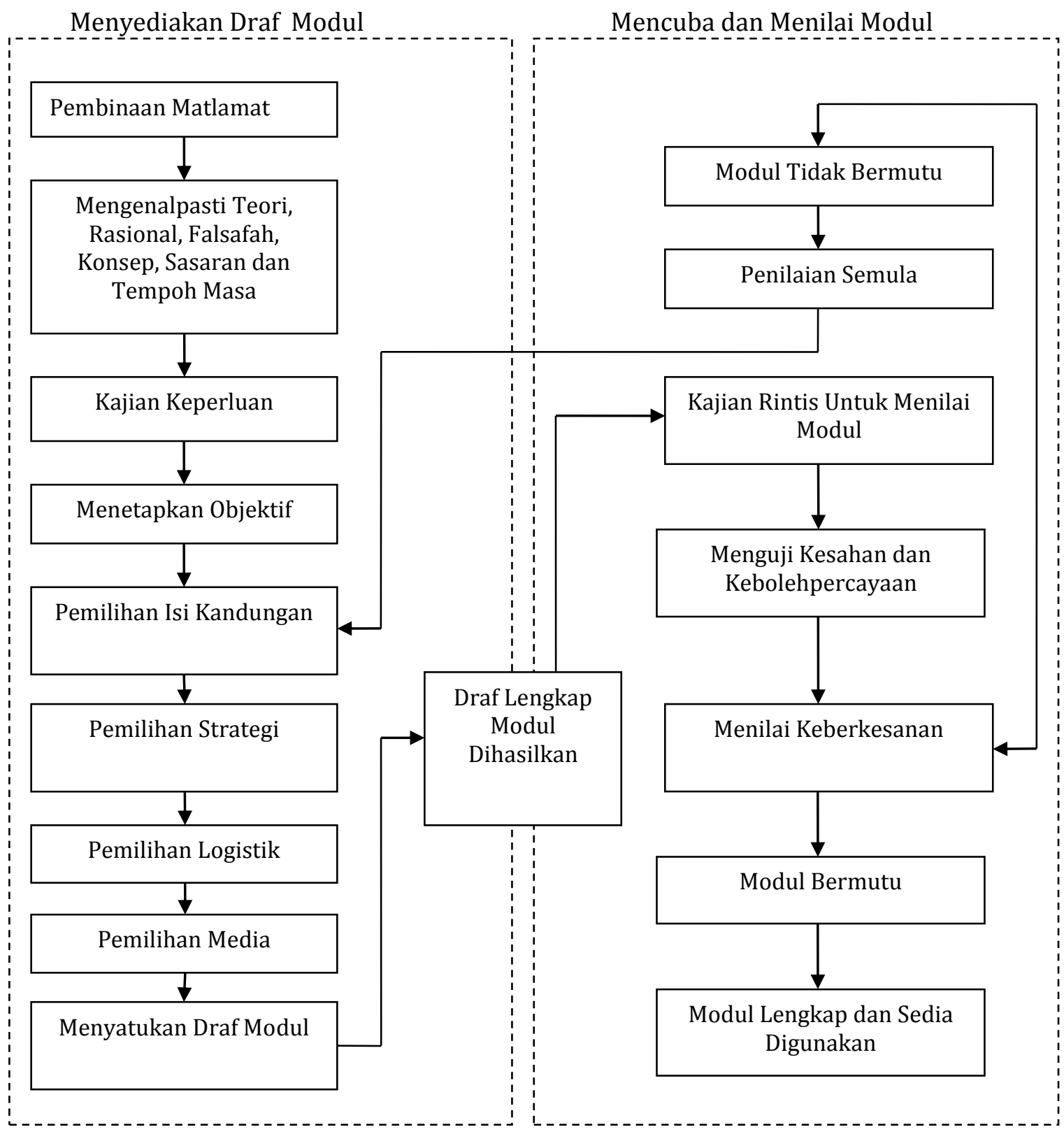

Pembinaan Modul Kaunseling Psiko Spiritual i-SC dalam kajian ini akan menggunakan model pembinaan modul Sidek kerana ia merupakan model integrasi yang komprehensif serta melalui proses percubaan atau kajian rintis untuk melihat kelemahan dan kekurangan yang ada. 
Seterusnya bagi memastikan modul yang bermutu akan diuji kesahan dan kebolehpercayaan dilakukan.

\section{Metodologi Kajian}

Kajian ini merupakan kajian tinjauan yang dilakukan untuk menguji kesahan dan kebolehpercayaan deraf modul yang dibina. Fokus utama adalah untuk mendapatkan nilai kesahan melalui respons secara bertulis oleh sekumpulan pakar dan nilai kebolehpercayaan melalui respon secara bertulis daripada sekumpulan subjek dalam kalangan pelajar yang bermasalah disiplin di sekolah.

Lokasi kajian tinjauan kesahan modul ini melibatkan pakar yang berkhidmat di Universiti Awam, Jabatan Kemajuan Islam Malaysia (JAKIM), Pengamal Kaunseling di institusi swasta di samping kaunselor di sekolah dan Institut Perguruan. Manakala lokasi kajian tinjauan kebolehpercayaan di lakukan di sebuah Sekolah Menengah Kebangsaan di Selangor.

Responden yang dipilih melibatkan tujuh orang pakar yang dilantik untuk membuat penilaian terhadap kesahan konstruk dan kandungan modul. Kumpulan pakar merupakan mereka yang mempunyai bidang kepakaran, pengalaman dan kesesuaian dengan modul yang dibina. Kriteria pemilihan kepakaran adalah: (i) Kepakaran dan pengetahuan berkaitan dengan bidang agama Islam seperti pendidikan Islam, usuludin dan tasawuf; (ii) Kepakaran dan pengetahuan dalam bidang psikologi dan kaunseling, dan (iii). Pengamal dalam bidang psikologi dan kaunseling. Profil panel pakar adalah seperti dalam jadual berikut:

Jadual 1: Profil Panel Kesahan Pakar

\begin{tabular}{llll}
\hline Bil. & Profil Ringkas & Institusi & Bidang Kepakaran \\
\hline 1. & Prof Dr (Pensyarah Universiti) & UKM & $\begin{array}{l}\text { Pembinaan modul, Kaunseling, } \\
\text { Dakwah }\end{array}$ \\
2. & Prof Madya Dr (Pensyarah Universiti) & UKM & Psikologi, Kaunseling \\
3. & Prof Madya Dr (Pensyarah Universiti) & UKM & Usuluddin dan Psikologi Islam \\
4. & Dr (Pensyarah Universiti) & UKM & Psikologi dan kaunseling \\
5. & Cr (Pengamal) & Konsultan & Psikologi dan kaunseling \\
6. & Cr (Kaunselor IPG) & IPG Ipoh & Kaunseling \\
7. & Cr (Pegawai Agama JAKIM) & JAKIM & Kaunseling \\
\hline
\end{tabular}

Responden kumpulan kedua merupakan 43 orang pelajar tingkatan empat yang terlibat untuk menguji nilai kebolehpercayaan modul i-SC. Mereka akan melalui aktiviti yang terdapat di dalam modul i-SC terlebih dahulu sebelum menjawab item kebolehpercayaan modul. Latar belakang pelajar adalah dari sekolah harian, berpencapaian akademik sederhana di samping mempunyai rekod tingkah laku disiplin kategori ringan dan sederhana. Pemilihan mereka adalah bersesuaian dengan kehendak kajian.

\section{Alat Kajian Kesahan Modul}

Kesahan modul merujuk kepada ketepatan konsep dan kandungan sesuatu modul. Pengkaji telah menyenaraikan pernyataan model Russel (1974) bagi memperoleh item kesahan modul yang mempunyai lima perkara iaitu: a) Menepati sasaran populasi; b) Situasi pengajaran atau kaedah perlaksanaan modul adalah bersesuaian; c) Masa yang diperuntukkan untuk menjalankan atau kaedah pelaksanaan modul adalah mencukupi; d) Modul berjaya 
menyebabkan berlakunya peningkatan pencapaian pelajar dalam aspek yang disasarkan; dan e) Modul berjaya mengubah sikap pelajar ke arah yang lebih cemerlang. Ini bermakna kesahan modul mestilah mengandungi ciri-ciri berkenaan.

Sesuatu alat ukuran dianggap sama maksud dengan modul. Ini adalah kerana alat ukuran dan modul merupakan alat, sumber, bahan yang menjadi panduan kepada seorang pembina modul untuk mendapatkan pelbagai maklumat dan data berkaitan dengan kajian dan penyelidikan yang akan dilakukan (Sidek \& Jamaludin 2005). Kesahan sesuatu modul akan menggambarkan sejauh mana hasil yang sepatutnya di capai. Ini bermakna modul yang mempunyai kesahan yang tinggi akan menghasilkan pencapaian mengikut objektif yang ingin diukur oleh pengkaji.

Kesahan modul i-SC akan dapat mengumpul data yang merangkumi kandungan modul yang sewajarnya ada di dalam modul berkenaan. Kesahan kandungan modul dianggap baik sekiranya ia dapat mengukur semua isi kandungannya dengan berkesan. Untuk menentukan kesahan sesuatu alat ukuran atau modul, kaedah yang boleh digunakan ialah dengan meminta maklum balas dan pandangan pakar (Mohd Majid 2000).

Dalam kajian ini, kesahan kandungan i-SC oleh kritikan luar (external criticism) dilakukan melalui pengesahan pakar untuk melihat kandungan dan aplikasi kelompok secara menyeluruh. Dua kaedah telah digunakan iaitu: a) Pengesahan berdasarkan kaedah Russel (1974) yang mempunyai lima pernyataan mengenai kesahan modul; dan b) Kesahan dari segi pembahagian konstruk (sesi) dan sub konstruk (aktiviti dalam sesi). Tujuh orang pakar telah dipilih berdasarkan kepakaran mereka dalam bidang keagamaan, bimbingan dan kaunseling, pembina modul dan sebagai ahli akademik. Perkara ini sejajar dengan proses kesahan modul yang dilakukan oleh Mohammad Aziz Shah (2010) serta Ahmad Jazimin et al. (2011), yang mana mereka telah melantik enam hingga sembilan orang pakar untuk membuat penilaian terhadap konstruk modul dan item kajian.

Pengkaji telah menyediakan satu salinan lengkap modul i-SC yang mengandungi pengenalan, objektif umum modul, asas teori, kandungan keseluruhan dan lampiran-lampiran modul yang disediakan untuk diteliti dan dinilai serta diberi cadangan oleh panel pakar. Satu set soal selidik kesahan kandungan modul berdasarkan pandangan Russell (1974) yang telah diubahsuai juga diberi kepada pakar untuk menentukan tahap isi kandungan modul i-SC.

Skala bagi penilaian ini ialah sepuluh mata pilihan iaitu 1 (sangat tidak setuju) hinggalah 10 (sangat setuju). Untuk menentukan tahap kesahan kandungan modul, maka jumlah skor yang telah diisi oleh pakar (x) akan dibahagikan dengan jumlah skor sebenar (y) dan didarabkan dengan seratus. Sesuatu modul itu mempunyai kesahan kandungan yang tinggi apabila memperoleh $70 \%$ dan dianggap telah menguasai atau mencapai tahap pencapaian yang tinggi (Tuckman 1988; Sidek \& Jamaludin 2005). Formula berkenaan adalah seperti berikut:

$$
\begin{gathered}
\text { Jumlah Skor Pakar (x) } \\
\hdashline \text { Jumlah Skor Sebenar (y) }
\end{gathered} \quad \text { 100\% } \quad \begin{gathered}
\text { Tahap Penguasaan } \\
\text { Kesahan Kandungan }
\end{gathered}
$$

\section{Alat Kajian Kebolehpercayaan Modul}

Kebolehpercayaan dikaitkan dengan konsistensi, ini bermakna sesuatu ujian dikatakan mempunyai kebolehpercayaan yang tinggi sekiranya skor yang sama diperoleh daripada individu yang sama pada masa yang berbeza (Sidek 2002). Menurut Mohammad Aziz Shah (2010), kebolehpercayaan modul merujuk kepada ketekalan dan kestabilan sesuatu modul di dalam merawat apa yang sepatutnya dirawat seperti di dalam objektif sesuatu modul. Pengujian kebolehpercayaan sesuatu modul boleh dilihat melalui sejauh manakah pelajar dapat mengikuti kandungan sesuatu modul berkenaan (Rusell 1974). 
Menurut Sidek dan Jamaludin (2005), kaedah menentukan kebolehpercayaan modul mempunyai persamaan dengan kaedah untuk menentukan kebolehpercayaan ujian atau alat ukuran. Hal ini kerana kedua-duanya merupakan alat yang dibangunkan khusus untuk tujuan tertentu. Untuk menguji nilai pekali kebolehpercayaan modul, kaedah membina soal selidik boleh dilakukan berdasarkan objektif sesuatu modul atau langkah-langkah pelaksanaan di dalam modul berkenaan (Jamaludin \& Sidek 2005). Kajian oleh Mohammad Aziz Shah (2010) dalam pembinaan modul peningkatan konsep kendiri telah membina item kebolehpercayaan berdasarkan langkah-langkah pelaksanaan modul dan memperoleh nilai pekali kebolehpercayaan .838. Manakala kajian oleh Jazimin et al. (2011) dalam pembinaan modul kaunseling kelompok CTRT juga membina item kebolehpercayaan berdasarkan langkahlangkah dan memperoleh nilai pekali kebolehpercayaan 0.830 .

Dalam kajian ini, kaedah dalam membina item-item bagi menentukan kebolehpercayaan i-SC adalah berdasarkan kepada objektif-objektif pada setiap aktiviti yang terdapat dalam i-SC seperti saranan Jamaludin dan Sidek (2005). Pemilihan berkenaan dibuat atas dasar pencapaian dan matlamat terhadap sampel akan tercapai apabila mereka memahami dan memenuhi sesuatu objektif yang telah digariskan di dalam modul berkenaan.

Penyelidik telah menyediakan set soal selidik berdasarkan objektif-objektif untuk menguji kebolehpercayaan i-SC. Set soal selidik ini diisi oleh sampel setelah mereka mengikuti dan menghabiskan setiap aktiviti. Soal selidik dianalisis bagi mendapatkan nilai kebolehpercayaan dengan menggunakan kaedah pekali alpha Cronbach. Menurut Mohd Majid (2000), sekiranya nilai kebolehpercayaan yang diperoleh tinggi, paling minima .60 bermakna modul i-SC mempunyai tahap konsistensi yang baik. Sebaliknya, nilai kebolehpercayaan yang tidak mencapai nilai .60, bermakna modul i-SC pada tahap konsistensi yang kurang baik dan perlu diperbaiki.

Dalam kajian ini, penentuan kebolehpercayaan, telah dilakukan terhadap 43 orang pelajar tingkatan empat yang mengikuti modul i-SC. Latar belakang pelajar adalah dari sekolah harian, berpencapaian akademik sederhana di samping mempunyai rekod tingkah laku disiplin kategori ringan dan sederhana. Soal selidik kebolehpercayaan modul diberikan kepada pelajar setelah mereka mengikuti setiap aktiviti dalam modul tersebut. Soal selidik telah dianalisis bagi mendapatkan nilai kebolehpercayaan dengan menggunakan kaedah pekali alpha Cronbach.

\section{Dapatan Kajian}

\section{Dapatan Kesahan Modul}

Dapatan kajian kesahan modul yang dilakukan oleh pakar yang dipilih dibincangkan berdasarkan soal selidik kesahan kandungan modul Russell (1974) yang telah diubahsuai untuk menentukan tahap isi kandungan modul i-SC. Hasil daripada penilaian pakar, nilai kesahan bagi keseluruhan kandungan iSC dapat dilihat dalam Jadual 2 berikut:

Jadual 2: Nilai Kesahan Kandungan Berdasarkan Penilaian Pakar

\begin{tabular}{lcc}
\hline $\begin{array}{l}\text { Pernyataan Berkaitan Sesi Kelompok/ Sub Modul i- } \\
\text { SC Yang Di Nilai }\end{array}$ & Peratusan & $\begin{array}{l}\text { Pandangan } \\
\text { Pakar }\end{array}$ \\
\hline $\begin{array}{l}\text { Kandungan modul ini menepati sasaran populasinya } \\
\text { Kandungan modul ini boleh dilaksanakan dengan } \\
\text { sempurna }\end{array}$ & 93 & Diterima \\
$\begin{array}{l}\text { Kandungan modul ini bersesuaian dengan masa yang } \\
\text { diperuntukkan }\end{array}$ & 90 & Diterima
\end{tabular}


Kandungan modul ini boleh meningkatkan kesedaran peserta

Kandungan modul ini boleh membantu mengubah tingkah laku disiplin pelajar
94

Diterima

$91 \quad$ Diterima

Jadual 2 menunjukkan nilai peratusan minimum ialah 90\% bagi pernyataan kandungan ini boleh dilaksanakan dengan sempurna dan pernyataan kandungan ini bersesuaian dengan masa yang diperuntukkan. Manakala peratusan maksimum ialah $94 \%$ bagi pernyataan kandungan modul ini boleh meningkatkan kesedaran peserta. Secara keseluruhannya dapatan berkenaan menunjukkan kandungan modul ini i-SC ini adalah bertepatan dan bersesuaian dengan sasaran modul berkenaan. Dapatan nilai kesahan pakar berdasarkan sesi dan aktiviti adalah seperti jadual berikut:

Jadual 3: Nilai Kesahan Pakar berdasarkan Sesi dan Aktiviti Modul i-SC

\begin{tabular}{|c|c|c|c|}
\hline Modul Utama & Sub Modul i-SC/Sesi & Peratusan & $\begin{array}{l}\text { Pandangan } \\
\text { Pakar }\end{array}$ \\
\hline Berkenalan & $\begin{array}{l}\text { Sesi 1: Pengenalan dan } \\
\text { Membina Hubungan }\end{array}$ & 90 & Diterima \\
\hline \multirow[t]{4}{*}{$\begin{array}{l}\text { Mengenali Diri } \\
\text { (Ma'rifah al-Nafs) }\end{array}$} & $\begin{array}{l}\text { Sesi } 2 \text { : Kenal Keistimewaan } \\
\text { Diri }\end{array}$ & 90 & Diterima \\
\hline & Sesi 3 : Kenal Matlamat Hidup & 90 & Diterima \\
\hline & $\begin{array}{l}\text { Sesi } 4 \text { : Kenalpasti Masalah } \\
\text { Diri }\end{array}$ & 90 & Diterima \\
\hline & $\begin{array}{l}\text { Sesi } 5 \text { : Kenalpasti Implikasi } \\
\text { Masalah }\end{array}$ & 94 & Diterima \\
\hline $\begin{array}{l}\text { Pembersihan Hati } \\
\text { (Takhalli) }\end{array}$ & Sesi 6 : Tindakan perubahan & 91 & Diterima \\
\hline $\begin{array}{l}\text { Pengisian Hati } \\
\text { (Tahalli) }\end{array}$ & Sesi 7 : Strategi Bertindak & 93 & Diterima \\
\hline $\begin{array}{l}\text { Muhasabah } \\
\text { (Penialian) }\end{array}$ & $\begin{array}{l}\text { Sesi } 8 \text { : Penilaian, } \\
\text { Perkongsian Celik Akal dan } \\
\text { Refleksi }\end{array}$ & 93 & Diterima \\
\hline $\begin{array}{l}\text { As-Saadah } \\
\text { (Saadah) }\end{array}$ & Sesi 9 : Penamatan & 91 & Diterima \\
\hline
\end{tabular}

Berdasarkan Jadual 3 menunjukkan peratusan keseluruhan sesi dan aktiviti modul i-SC melebihi $90 \%$ bagi setiap sesi dan aktiviti. Peratusan minimum $90 \%$ adalah bagi aktiviti kenal keistimewaan diri, kenal matlamat hidup dan kenal masalah diri. Manakala peratusan maksimum $94 \%$ bagi aktiviti implikasi masalah. Ini bermakna tahap kesahan modul i-SC adalah boleh dipercayai. Pakar juga telah memberikan komen secara bertulis berkaitan kandungan modul agar dilakukan penambahbaikan. Antara komen pakar adalah seperti jadual berikut: 
Jadual 4: Komen Penambahbaikan Kandungan Modul Oleh Pakar

\begin{tabular}{|c|c|}
\hline Pakar & Penambahbaikan \\
\hline Pakar 1 & $\begin{array}{l}\text { Fokus untuk kenal diri fizikal dan spiritual. Sebaiknya ada refleksi bagi setiap sesi. } \\
\text { Sebaiknya digabungkan sesi } 6 \text { dan sesi } 7 .\end{array}$ \\
\hline Pakar 2 & $\begin{array}{l}\text { a. Modul sesuai untuk golongan sasaran } \\
\text { b. Modul keseluruhan adalah baik tetapi pembahagian aktiviti } \\
\text { hendaklah sesuai dengan proses } \\
\text { c. Item-item atau istilah perlu dikaji semula untuk diesuaikan dengan istilah } \\
\text { psikologi dan terminologi kelompok bimbingan dan keperluan sasaran }\end{array}$ \\
\hline Pakar 3 & $\begin{array}{l}\text { a. Aktiviti perlu diperkemaskan } \\
\text { b. Dicadangkan istilah arab diubah ke bahasa Melayu }\end{array}$ \\
\hline Pakar 4 & Perkemaskan sesi taaruf agar dapat mewujudkan ahli lebih jelekit \\
\hline Pakar 5 & $\begin{array}{l}\text { Modul yang baik untuk untuk dilaksanakan kepada pelajar, juga boleh diluaskan } \\
\text { kepada sasaran dakwah yang lain }\end{array}$ \\
\hline Pakar 6 & $\begin{array}{l}\text { a. Ringkaskan borang biodata diri } \\
\text { b. Langkah-langkah aktiviti dikemaskini dengan masa yang tepat } \\
\text { c. Modul ini dapat membantu peserta mengenali asas-asas positif atau negatif serta } \\
\text { diri fizikal peserta } \\
\text { d. Modul ini dapat membantu peserta mengenal ciri spiritual dalam merawat hati di } \\
\text { samping dapat mengetahui/mengenali sebab/akibat tindakan diri } \\
\text { e. Modul ini telah disusun mengikut standard pembinaan modul } \\
\text { f. Sangat baik utuk dilaksanakan terhadap peserta bermasalah tingkah laku }\end{array}$ \\
\hline Pakar 7 & $\begin{array}{l}\text { a. Dicadangkan gunakan perkataan-perkataan Bahasa Melayu ganti perkataan arab. } \\
\text { Untuk mengelakkan salah faham } \\
\text { b. Dicadangkan masukkan homework bagi setiap sesi }\end{array}$ \\
\hline
\end{tabular}

Berdasarkan komen yang dikemukakan oleh pakar, pemurnian modul telah dilakukan. Secara keseluruhannya berasaskan respons daripada pakar-pakar penilai terhadap sub konstruk modul, menunjukkan modul i-SC ini menepati objektif-objektif yang telah dinyatakan.

\section{Dapatan Kajian Kebolehpercayaan Modul}

Dapatan pengujian kebolehpercayaan berdasarkan sesi dan aktiviti i-SC telah dijalankan ke atas pelajar menggunakan analisis alpha cronbach adalah seperti berikut:

Jadual 5: Nilai Kebolehpercayaan i-SC keseluruhan

\begin{tabular}{lc}
\hline Modul & Nilai $\boldsymbol{\alpha}$ \\
\hline $\begin{array}{l}\text { Modul Kaunseling Psiko Spiritual i-SC (Islamic Spiritual } \\
\text { Counseling) }\end{array}$ & .927 \\
\hline
\end{tabular}


Jadual 6: Nilai Kebolehpercayaan Sesi dan Aktiviti Modul Kaunseling Psiko-Spiritual i-SC

\begin{tabular}{|c|c|c|}
\hline Modul Utama & Sub Modul i-SC/Sesi & Nilai $\alpha$ \\
\hline $\begin{array}{l}\text { Berkenalan } \\
\text { (Taaruf) }\end{array}$ & $\begin{array}{l}\text { Sesi 1: Pengenalan dan } \\
\text { Membina Hubungan }\end{array}$ & .900 \\
\hline \multirow[t]{4}{*}{$\begin{array}{l}\text { Mengenali Diri } \\
\text { (Ma'rifat al-Nafs) }\end{array}$} & $\begin{array}{l}\text { Sesi } 2 \text { : Kenal Keistimewaan } \\
\text { Diri }\end{array}$ & .871 \\
\hline & $\begin{array}{l}\text { Sesi } 3 \text { : Kenal Matlamat } \\
\text { Hidup }\end{array}$ & .859 \\
\hline & $\begin{array}{l}\text { Sesi } 4 \text { : Kenalpasti Masalah } \\
\text { Diri }\end{array}$ & .873 \\
\hline & $\begin{array}{l}\text { Sesi } 5 \text { : Kenalpasti Implikasi } \\
\text { Masalah }\end{array}$ & .888 \\
\hline $\begin{array}{l}\text { Pembersihan Hati } \\
\text { (Takhalli) }\end{array}$ & Sesi 6 : Tindakan perubahan & .862 \\
\hline $\begin{array}{l}\text { Pengisian Hati } \\
\text { (Tahalli) }\end{array}$ & Sesi 7 : Strategi Bertindak & .868 \\
\hline $\begin{array}{l}\text { Muhasabah } \\
\text { (Penilaian) }\end{array}$ & $\begin{array}{l}\text { Sesi } 8 \text { : Penilaian, } \\
\text { Perkongsian Celik Akal dan } \\
\text { Refleksi }\end{array}$ & .876 \\
\hline $\begin{array}{l}\text { al-Sa'adah } \\
\text { (Sa'adah) }\end{array}$ & Sesi 9 : Penamatan & .871 \\
\hline
\end{tabular}

Berdasarkan kajian rintis i-SC nilai kebolehpercayaan keseluruhan adalah baik melebihi aras .60 iaitu .927. Nilai alpha tertinggi adalah .900 bagi aktiviti pengenalan diri dan nilai alpha terendah adalah 859 bagi aktiviti kenal matlamat hidup. Dapatan berkenaan menunjukkan i-SC boleh diterima dan dipercayai serta boleh digunakan dalam intervensi dalam meningkatkan religiositi dan resilensi pelajar.

\section{Perbincangan}

Kajian ini bertujuan untuk membina modul kaunseling spiritual berperspektif Islam yang dikenali sebagai Modul Kaunseling Psiko Spiritual i-SC (Islamic Spiritual Counseling). Modul iSC berteraskan elemen agama dan penggunaannya sebagai intervensi berjaya membuktikan modul keagamaan mempunyai peranan terhadap perkembangan individu secara positif. Keperluan elemen agama sebagai intervensi telah diperakui oleh beberapa organisasi profesional seperti American Psychological Association (APA) dan American Counseling Association yang mengiktiraf dan mengakui bahawa agama adalah satu elemen yang memberi sumbangan kepada perkembangan dan kefungsian manusia. APA telah meletakkan religiositi pada division ke 36 sebagai salah satu bahagian daripada beberapa bahagian psikologi yang diiktiraf (APA 2011). 
Modul i-SC boleh dianggap sebagai modul yang lengkap kerana ia telah melalui kajian kesahan dan kebolehpercayaan bertepatan dengan prosedur pembinaan modul model Sidek (Sidek \& Jamaludin, 2005) yang mana modul yang bermutu dan dianggap lengkap setelah diuji kesahan dan kebolehpercayaannya. Dalam pembinaan modul latihan dan intervensi, pengkajipengkaji sebelum ini turut melakukan ujian kesahan bagi memastikan kandungan modul yang mereka telah bina benar-benar menepati keperluan dan boleh digunakan kepada sasaran populasi. Pengkaji-pengkaji berkenaan termasuklah kajian pembinaan modul oleh Nik Zaharah (2007), Mohammad Aziz Shah (2010), dan Ahmad Jazimin et al. (2011).

Kesahan modul melalui kesahan kandungan oleh penilai luar telah dilakukan terhadap modul i-SC. Dapatan daripada kesahan kandungan oleh pakar mendapati kandungan modul i-SC merangkumi kandungan modul yang sewajarnya, sesuai dengan sasaran populasi, menepati objektif yang telah digariskan di samping peruntukan masa yang bersesuaian. Perkara ini sesuai dengan pandangan Russel (1974), bagi sesuatu modul penilaian kesahan hendaklah mempunyai lima perkara iaitu: a) Menepati sasaran populasi; b) Situasi pengajaran atau kaedah perlaksanaan modul adalah bersesuaia; c) Masa yang diperuntukkan untuk menjalankan atau kaedah pelaksanaan modul adalah mencukupi; d) Modul berjaya menyebabkan berlakunya peningkatan pencapaian pelajar dalam aspek yang disasarkan; dan e) Modul berjaya mengubah sikap pelajar ke arah yang lebih cemerlang. Kesahan kandungan turut dilakukan oleh pengkaji sebelum ini terhadap modul mereka iaitu oleh Mohammad Aziz Shah (2010) juga kajian oleh Ahmad Jazimin et al. (2011).

Dapatan kebolehpercayaan i-SC keseluruhan adalah baik melebihi aras 0.60 iaitu 0.927. Menurut Mohd Majid (2000), sekiranya nilai kebolehpercayaan yang diperoleh tinggi, paling minima 0.60 bermakna modul i-SC mempunyai tahap konsistensi yang baik. Ini bermakna i-SC boleh diterima dan dipercayai serta boleh digunakan dalam intervensi. Proses mendapatkan nilai kebolehpercayaan ini sejajar dengan apa yang telah dilakukan oleh pengkaji sebelum ini terhadap modul mereka oleh Mohd Ali et al. (2009), Mohammad Aziz Shah (2010) juga kajian Ahmad Jazimin et al. (2011).

Kandungan modul merupakan antara perkara utama dalam sesebuah modul. Modul keagamaan memerlukan kandungan yang menepati kehendak agama dan keperluan sasaran. Kandungan modul i-SC disusun dan disatukan mengikut tahap perkembangan bermula dari pra sesi sehinggalah kepada penamatan. Ini adalah bertepatan dengan kajian Nik Zaharah (2007) dan Mohammad Aziz Shah (2010) yang mana isi kandungan sesuatu modul perlu disenaraikan, dipilih dan disaring agar benar-benar bersesuaian dan bertepatan. Ini penting bagi memastikan ia dapat mencapai objektif yang ditentukan.

Kajian ini telah berjaya mengetengahkan satu kerangka teoretikal yang komprehensif dalam pendekatan bimbingan dan kaunseling perspektif Islam. Pemikiran Imam al-Ghazali berkaitan proses tazkiyat al-nafs telah dijadikan asas dalam pembinaan kerangka teori berkenaan. Model ini juga telah dijadikan sandaran teori dalam pembinaan i-SC. Pemikiran al Ghazali berkaitan penyucian diri begitu komprehensif yang meletakkan pembentukan diri secara bertahap mengikut latar diri seseorang. Ini bertepatan dengan pandangan pengkaji sebelum ini yang mana Imam al-Ghazali boleh dianggap sebagai pelopor kepada ahli psikologi Islam dan telah mengetengahkan pandangan terhadap pembinaan personaliti dengan terperinci (Sapora 2007; Salasiah 2008).

Kajian ini membuktikan modul keagamaan khususnya dari perspektif Islam boleh dibangunkan secara empirikal berdasarkan garis panduan dan prosedur pembinaan modul yang sempurna. Dapatan kesahan dan kebolehpercayaan membuktikan i-SC boleh digunakan sebagai salah satu pendekatan dalam proses membantu.

Secara keseluruhannya kajian ini menjelaskan tentang kesahan. Berdasarkan dapatan, kesahan modul i-SC adalah tinggi berdasarkan kepada penilaian pakar. Ini menunjukkan modul ini mampu memberikan implikasi yang signifikan dalam membantu menangani isu salahlaku pelajar. 


\section{References}

Ahmad Jazimin Jusoh, Abdul Malek Abdul Rahman, Mohammad Nasir Bistamam \& Mohammad Aziz Shah Mohamed Arip. 2011. Modul Kaunseling Kelompok CTRT: Pendekatan Menangani Permasalahan Disiplin Pelajar. Tanjong Malim: Penerbit Universiti Pendidikan Sultan Idris.

Allen, Jackie, M., Coy \& Rhea, D. 2004. Linking Spirituality and Violence Prevention in School Counseling. Professional School Counseling 7(5): 351-355.

American Psycological Association. atas talian. http://www.apa.org/about/ division/ div36.aspx.

Burke, T.M., Chauvin, J.C. \& Judith G.M. 2005. Religious and Spiritual Isues in Counseling. New York: Brunner-Routledge.

Graham, S., Furr, S., Flores, C. \& Burke, M.T. 2001. Religion and spiritual in coping with stress. Counseling and Values, 46, 2-13.

al-Ghazali. 2007. Ihya Ulumuddin. Transl. Ismail Yakub. Singapura: Pustaka Islamiyah.

Hall, R.E. \&c Livingston, J.N. 2006. Mental health practice with Arab families: The Implications of spirituality vis-à-vis Islam. The American Journal of Family Therapy. 34: 39-50.

Haron Din. 2002. Manusia dan Islam. Kuala Lumpur: Dewan Bahasa dan Pustaka.

Mohammad Aziz Shah Mohamed Arip, Md. Noor Saper, Samsiah Jais, Aslina Ahmad, Nurul Yakin Supeni. 2014. Pembinaan Kesahan dan Kebolehpercayaan Modul Transfromasi Ehsan Pusat Perlidungan Wanita Baitul Ehsan, Sabak Bernam, Geran Penyelidikan MAIS.

Mohd Majid Konting. 2000. Kaedah Penyelidikan Pendidikan. Ed. Ke-5. Kuala Lumpur: Dewan Bahasa dan Pustaka.

Nik Zaharah Nik Yaacob. 2007. Kajian Penerapan Nilai Murni Menerusi Pengajaran Bermodul. Tesis Dr. Fal. Universiti Kebangsaan Malaysia. Bangi.

Sapora Sipon. 2009. Keperluan elemen agama dalam disiplin ilmu kaunseling. Dlm Sapora Sipon, Abd Halim Mohd Hussin, Zuria Mahmud \& Rusnani Abdul Kadir (pnyt.). Isu-Isu Kaunseling di Malaysia. Kuala Lumpur: PERKAMA.

Rusell, J.D. 1974. Modular Instruction: A Guide to the Design, Selection, Utilization and Evaluation of Modular Materials. United States: Publishing Company.

Sidek Mohd Noah \& Jamaludin Ahmad. 2005. Pembinaan Modul: Bagaimana Membina Modul Latihan dan Modul Akademik. Serdang: Penerbit Universiti Putra Malaysia.

Ramli Awang. 1997. Tasawwur Rabbani Menurut al-Quran dan al-Sunnah. Kuala Lumpur: Penerbit Hizbi Sdn. Bhd.

Salasiah Binti Hanin Hamjah \& Noor Shakirah Mat Akhir. 2007. Riyadah al-Nafs menurut alGhazali dan aplikasinya dalam launseling di Pk Mains. Jurnal Usuluddin 26: 45-62.

Tuckman, B.W. 1988. Conducting Educational Research. 3rd Edition. New York: Harcourt Brace Jovanovich, Inc.

Wan Abd. Kader Wan Ahmad \& Ismail Abdul Ghani. 2006. Islam dan kaunseling: Satu penilaian kritikal terhadap teori dan pendekatan. Dlm. Dakwah dan Kaunseling di Malaysia. Fariza Md Sham, Siti Rugayah Tibek Othman Talib (pnyt). Bangi: Penerbit Universiti Kebangsaan Malaysia. 